\title{
The Impact of Credit Constraints on Exporting Firms: Evidence from the Provision and Subsequent Removal of Subsidized Credit
}

\author{
Mudit Kapoor ${ }^{\text {a }}$ \\ andian School of Business, Hyderabad; Email: mudit_kapoor@isb.edu \\ Priya Ranjan ${ }^{b}$ \\ ${ }^{\mathrm{b}}$ Department of Economics, University of California, Irvine Email: pranjan@uci.edu \\ Jibonayan Raychaudhuri (Corresponding Author) ${ }^{\mathrm{c}}$ \\ 'Department of Economics, University of East Anglia, Norwich Email: j.raychaudhuri@uea.ac.uk
}




\begin{abstract}
We study the causal impact of credit constraints on exporters using a natural experiment provided by two policy changes in India, first in 1998 which made small-scale firms eligible for subsidized direct credit, and a subsequent reversal in policy in 2000 wherein some of these firms lost their eligibility. Using firms that were not affected by these policy changes as our control group, we find that credit expansion increased the growth rate of bank borrowing and had a positive effect on exports.The subsequent policy reversal in 2000 had no impact on the growth rate of bank borrowing or on exports.
\end{abstract}

Key words: finance, credit constraints, trade, export probability.

JEL Classification: F13, G15, G18, G21. 


\section{InTRODUCTION AND Motivation}

Subsidized credit given by the government to exporting firms has played an important role in the rapid export-oriented growth of East Asian countries (see for example, Kokko [2002] for a detailed discussion of the growth experiences of Japan, Hong Kong, Singapore and Taiwan). Firms that export are usually larger firms (in terms of employment) and better performing firms than non-exporting firms (Bernard and Jensen [1999]) and so credit directed at exporting firms is of considerable importance in increasing economy wide employment and growth.

In this paper we contribute to the empirical literature on the export-finance linkage. We study the effects of government provision of and subsequent removal of subsidized credit on the real outcomes of exporting firms (firm sales, export earnings, etc.) for a panel of Indian firms. We make use of two exogenous policy changes in India that affected how much subsidized credit was available to small-scale firms. The first policy change, introduced in 1998, changed the eligibility criteria for subsidized credit to be given to small-sized firms. As a result of this policy change, some of the small sized firms were classified as "priority sector firms" and became eligible for the first time to get subsidized credit from the banks. However, in 2000, some of these firms (which had newly become part of the priority sector) were removed from the priority sector and were no longer eligible to get subsidized credit from the banks.

We use firms that were affected by these policy changes as our treatment group (in each case). For each of these treatment group firms we use firms not affected by these policy changes as our comparison group (in each case). We find that subsidized credit provided to newly eligible firms increased the rate of growth of total bank borrowing for these newly eligible firms by 20 percent and increased their rate of growth of exports by approximately 24 percent (these growth rates are growth rate differences for these firm outcomes compared to the growth rates of control group firms in each case). Our empirical results suggest that even exporting firms that have overcome their sunk costs of exporting are sensitive to credit constraints. Interestingly, the subsequent reversal of the 1998 policy in 2000 had little impact on bank lending and on the export earnings of the firms that were now declassified as priority sector firms and had lost their eligibility for subsidized credit. One possible conclusion of our result is that, perhaps, before the policy change in 1998, Indian banks were reluctant to lend (or were under lending) to small sized firms even if these small sized firms wanted to borrow more at the current market interest rates. The policy change forced the banks to change their behavior towards these firms. However, once it was established that expanding the credit limit did not lead to increased defaults or risky financial behavior on the part of these firms, there was no reason for the banks to alter their relationship with these firms even after the policy reversal.

A paper on banking reforms in India by Bannerjee, Cole, and Duflo [2004] (hereafter referred to as BCD) finds evidence of massive under lending by banks, and in particular, by nationalized banks. They also find that the official lending policy of banks is very rigid and is characterized by passive lending, primarily due to the aggressive vigilance activity that inhibits lending to the private sector and encourages lending to the government sector. A key policy implication of our paper is that financial sector reforms in emerging economies that improve the access of credit to exporting firms can play a very significant role in promoting export oriented growth in the economy. This is specially true for developing countries for which a number of studies have shown clear evidence of under lending (see Bannerjee, Cole, and Duflo [2004]).

Our results for the credit expansion phase of the policy change are similar to those obtained in Bannerjee and Duflo [2014] who use the same natural experiment but on a different and a much smaller data set and find that Indian firms (their sample is not limited to only exporters, like our sample of firms) are credit constrained and that the expansion of credit leads to a higher growth in firm sales. ${ }^{1}$ However,

\footnotetext{
${ }^{1}$ Bannerjee and Duflo [2014] have a unique dataset comprising of firms which are clients of a large public bank in India. While they are able to more accurately identify firms that are eligible for priority sector lending from the bank's survey data, their analysis is limited only to firms that receive loans from a single bank. This limitation might pose a threat to external validity. In contrast, we consider a panel of firms which spans the entire industrial composition in Indian manufacturing. Our sample includes both listed as well as unlisted firms and so it
} 
and in contrast to their results, we find that the credit contraction phase of the policy change had no impact on the sales or on the exports of firms that lost their eligibility, whereas they find that the contraction of credit leads to a reduction in the sales of firms that lost their eligibility for priority sector lending. Another novelty of our paper (as mentioned earlier) is that we focus our attention on firms that are exporters in the manufacturing sector. Another paper which is very similar to our paper is the work by Zia [2008] who finds that small private non-networked yarn manufacturers in Pakistan suffer a significant decline in exports after the removal of subsidized state credit. Another empirical paper of interest is Minetti and Zhu [2011]. ${ }^{2}$ Like our paper, these authors use a panel of Italian firms to look at the effect of credit rationing specifically on a firm's exports. In contrast to our paper, they look at the survey response of a firm, in their analysis, instead of relying on a firm's internal financial records. They control for obvious confounders (like productivity) and use an instrumental variables approach to account for the endogeneity between credit rationing and a firm's export status (in contrast to a natural experiment as in our case). They find results similar to our study - credit rationing lowers the probability of a firm entering export markets by as much as $39 \%$ and also has an effect on the intensive margin by lowering foreign sales by $38 \%$. They also find that these credit constraints have a negative effect on domestic sales.

Our paper adds to the burgeoning literature that uses firm level data to empirically establish export-finance linkages. A notable early study in this area is by Beck [2003] and other studies include Campa and Shaver [2002] for Spanish exporters, Guariglia and Mateut [2010] for U.K. firms, Paravisini, Rappoport, Schnabl, and Wolfenzon [2011] for Peruvian exporters, Egger and Kesina [2013] for large Chinese exporters and Manova [2013]. Similar to our results these studies also find evidence of financial constraints affecting export behavior both at the extensive and at the intensive margin. However, a key differentiating factor in our paper is that to establish our results we exploit a natural experiment induced by a policy change, which leads to an exogeneous variation (increase) in the amount of subsidized credit provided to firms and then a subsequent policy reversal which leads to yet another exogenous variation (decrease) of this subsidized credit provided to these firms. ${ }^{3}$

Our paper is organized as follows. In section 2 , we briefly discuss the Indian banking sector and the policy change; in section 3, we describe our data set; in section 4, we explain our estimation methodology and discuss the results and discuss some identification issues with our sample. Section 5 concludes.

\section{The Indian Banking Sector, Priority Sector Regulation and The Policy Change}

2.1. The Indian Banking Sector. In recent years, the Indian banking sector has seen the emergence of private banks and many large foreign banks. However, the banking sector is still (by and large) dominated by public sector (and nationalized) banks (these are corporatized banks where the government is the majority shareholder). For example, 78 percent of total deposits are collected by nationalized banks, 77 percent of total loans and advances are made by the nationalized banks and about 83 percent of banking

is not limited only to publicly traded firms. The fact that we use a different database can plausibly explain why we obtain results different from Bannerjee and Duflo [2014] (for the credit contraction phase). Another reason that could account for the difference in our results could be lagged treatment effects possibly because of having fewer years in our sample after the second change in policy contracted credit for some of the firms.

${ }^{2}$ We would like to thank an anonymous referee for bringing this paper to our attention.

${ }^{3}$ A substantive theoretical literature on trade-finance linkages has also developed in parallel to the empirical literature using the framework pioneered by Melitz [2003]. For example, Manova [2013] develops a model of credit constrained firms across countries and shows that countries at a higher level of financial development export more and also that firms in "financially vulnerable" sectors export more in countries that are more financially developed compared to countries that suffer from weaker financial markets. Muûls [2008] incorporates financial constraints both external and internal to a firms in a Melitz type set-up and finds results similar to that of Manova [2013] wherein both the extensive as well as the intensive margins of trade are affected by credit constraints. Using a Melitz-type setup, Chaney [2013] finds that both liquidity constraints and firm productivity influence the extensive margin of trade whereas only firm productivity influences the intensive margin of trade. Feenstra, Li, and Yu [2014] develop a model in which they differentiate between credit constraints facing firms manufacturing solely for the domestic market versus exporting firms. They show that the time lags involved in shipping exports coupled with the incomplete knowledge that banks have of firms' productivity and end use of funds leads to tighter credit constraints on exporters than on purely domestic firms. 
deposit shares are held by state owned or nationalized banks. In addition to the term loans, nationalized banks also issue approximately 37 percent of total loans and advances in the form of cash credits and overdraft facilities which are typically used by firms to take care of their short-term working capital needs. ${ }^{4}$ Despite the dominance of these nationalized banks, the Indian banking system is characterized by under-lending, that is, firms are willing to absorb more credit at the market interest rates than what they are actually given. ${ }^{5}$ BCD have noted that public sector banks in India were until very recently intensely regulated by the Reserve Bank of India (RBI). For example, the RBI determined the "maximum permissible bank finance" for individual borrowers. For loans over $R s .20$ million, the lending rule was based on the working capital gap. This rule was $0.75 *$ [Current Assets - Current Liabilities] (excluding bank finance). For loans below $R s$. 20 million, the lending rule was based on the projected turnover. Here the rule was [0.20*Projected Turnover] where the turnover was determined by the loan officer after consultation with the client. After 1997, based on the Nayak committee recommendation, the banks were given the flexibility to evolve their own lending policy as long as these policies were made explicit. Moreover, the committee's recommendation favoured the turnover-based approach to calculate the lending limits for all loans below $R s .40$ million. However, even after 1997, the RBI played an important role in determining the banks lending policy to individual borrowers.

In a study of the actual lending practices of public sector banks, BCD have also observed that despite the change in lending policies, in 78 percent of the cases, the actual limit granted was smaller than the maximum amount of loan that was permitted. In 64 percent of the cases, the limit granted did not change from the previous year in spite of the fact that according to the bank's lending rules, the limit could have gone up for 64 percent of the cases. The evidence from BCD suggests that nationalized banks in India were reluctant to engage in fresh lending decisions. Inertia plays a very important role in explaining the behavior of loan officers in public sector banks.

Another important feature of the Indian banking sector that could explain under-lending is the incentive structure faced by the loan officers. Given that nationalized banks are owned by the government, the loan officer is treated as a public servant. The general impression among loan officers is that it is very easy to be charged with corruption because anti-corruption laws in India state that if any public servant takes a decision which results in a financial gain to a third party, then the public servant is guilty of corruption till proven innocent. BCD have shown that the fear of being prosecuted reduces lending by loan officers in a significant way.

\subsection{Priority Sector Regulation. To promote credit to the priority sector which consists of the agricul-} tural sector, the small scale industries (SSI hereafter) and "the weaker sections of the society" (for example microcredit, self-help groups, self-employed household, etc.), the Government of India mandates that 40 percent of net bank credit should be reserved for the priority sector. ${ }^{6}$ This limit is 32 percent for foreign banks. In addition, the net bank credit to the agricultural sector cannot be less than 18 percent and the net bank credit to the aforementioned "weaker sections" cannot be less than 10 percent. The credit to the priority sector can be in the form of either direct finance which is given in the form of short-term, medium term or long term loans or in the form of indirect finance, for example, "...term finance/loans in the form of

\footnotetext{
${ }^{4}$ These figures are from Bannerjee, Cole, and Duflo [2004].

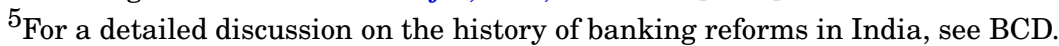

${ }^{6}$ An anonymous referee raised the point that increasing the set of firms that are part of the priority sector should increase the competition for bank credit within this set of firms. One possible effect of this increased competition for bank funds could be that firms with investment in plant and machinery of less than $R s .6 .5$ million might suddenly become credit constrained having to compete with firms newly admitted to the priority sector (those with investment in plant and machinery between $R s .6 .5$ million to $R s$. 30 million). This is an important point which has implications for the interpretation of our results and our identification strategy. We note that from the policy point of view, simply allowing more firms to become eligible for priority sector lending doesn't ease the credit constraint for all firms below the cutoff because the total amount of credit remains the same. The purpose of our exercise is not to study the effectiveness of the policy in question but to use the policy change to study if firms are credit constrained and how they would respond to a relaxation of credit constraint. As far as the identification is concerned, since firms below 6.5 have to now compete with those between 6.5 and 30 for credit, they are at a disadvantage now, and therefore, it justifies including them in the control group.
} 
lines of credit made available to State Industrial Development Corporation (SIDBI)/State Financial Corporations (SFCs) for financing SSIs. Such term finance/loans to the extent granted for/to the Small Scale Industrial (SSI) units, will be treated as priority sector lending" (as outlined in the Reserve Bank of India Circular [2006] of the RBI on lending to the Priority sector). The interest rates for priority sector lending is determined by the RBI and it changes from time to time. For example, during the period of this study, the interest rate was fixed at four percent above the prime lending rate.

2.3. Policy Change. Prior to 1998, firms with a total investment in plant and machinery of less than $R s .6 .5$ million were classified as SSI and hence were eligible for priority sector lending. In January 1998, the government broadened the domain of the priority sector by broadening the definition of SSI all firms with investment in plant and machinery of less than $R s .30$ million were now classified as SSI and therefore became eligible for priority sector lending. In January 2000 , this policy change was partly undone by yet another change in the definition of SSI - firms with investment in plant and machinery of less than $R s .10$ million were now eligible for priority sector lending while firms with investment in plant and machinery greater than $R s .10$ million but less than $R s .30$ million were now declassified as priority sector and hence were not eligible for priority sector lending. These two policy changes form the basis of our "natural experiment". For the years 1999, 2000 all new firms that became eligible for priority sector lending form the treatment group (these are firms with an investment in plant and machinery between $R s$. 6.5 million to $R s$. 30 million) while from 2001 till 2005 (the final year of our sample) all firms that lost their eligibility form the treatment group (these are firms with an investment in plant and machinery between $R s .10$ million to $R s .30$ million).

\section{DATA}

The data for our paper comes from the Prowess database from the Centre for Monitoring the Indian Economy (CMIE), a private think-tank that provides firm level data on all companies that are traded on India's major stock exchanges and several other PSU's (Public Sector Undertaking) as well as for unlisted companies. The Prowess database comprises of more than 10 years of data and is updated on a daily basis. The coverage of Prowess is extensive-all the firms put together account for 75 percent of corporate taxes and 95 percent of the excise duty collected by the Indian government. For all these firms, Prowess contains detailed data (compiled from firm's audited annual accounts, stock exchanges, company announcements, etc.) on 1500 items which include quantitative information on firm's production, sales, export earnings, expenditure on capital goods, raw materials, power and fuel, labour, etc. It also contains detailed data on financial variables like the amount of bank borrowing, other financial institutional borrowing, secured and unsecured debt. The database also categorizes firms by industry type according to the 4-digit 1998 NIC code (Indian equivalent of the SIC classification scheme). The list of firms spans the industrial composition of the Indian economy. ${ }^{7}$

In this paper we use firm level data from 1994 to 2005. In table 1, we provide summary statistics for the firms in our sample for some of the key variables that we use in our study like sales, exports, total bank borrowings etc. Our focus is on the impact of the policy change on exporting firms in particular.

\section{[Insert Table 1]}

\section{EMPIRICAL ANALYSIS}

4.1. Credit Constraints and Exports. We use the difference-in-differences estimation strategy to estimate the causal impact of credit constraints on exporting firms by exploiting a natural experiment provided by two policy changes. The first policy change in 1998 made small scale firms eligible for subsidized

\footnotetext{
${ }^{7}$ From the Prowess Database web site at CMIE.
} 
credit. The second policy change in 2000 was a reversal of the 1998 policy when some firms lost their eligibility. We follow a two step procedure to isolate the effects on firm performance of these two policy changes. First we study the impact of the expansion of credit on different variables of firm performance and then we look at the impact of the subsequent contraction of credit on the same variables.

In our first step, we look at the impact of the credit expansion in 1998 on the rate of growth of several financial and real variables for the firms that became newly eligible for priority sector lending in 1998. To see this, we run a regression of the following form ${ }^{8}$ :

$$
\begin{aligned}
\ln (y)_{i t}-\ln (y)_{i t-1} & =\alpha_{0}+\sum_{t} \alpha_{t} \text { Time }_{t}+\beta_{1} \text { SizeDummy } 1_{i} \\
& +\beta_{2} \text { YearDummy } 1_{t}+\beta_{3} \text { SizeDummy } 1_{i} \times \text { YearDummy } 1_{t} \\
& +\mathbf{X}_{i t} \gamma+\varepsilon_{i t}
\end{aligned}
$$

where $\ln (y)_{i t}$ denotes the log of $y_{i t}$ and $y_{i t}$ in turn represents three different financial variables, viz., (i) total bank borrowing (ii) short term bank borrowing and (iii) interest payments and two real variables, viz., (i) sales and (ii) exports. ${ }^{9}{ }^{10}$ We note that having the dependent variable in differenced form in the above specification helps mitigate autocorrelation (for example, the current amount loaned could be very strongly autocorrelated with past loans). Time $_{t}$ is a time dummy for year $t$ that controls for the general time trends that affect all firms, SizeDummy $1_{i}$ is a dummy variable that is equal to 1 if the firm is (newly) classified as a priority sector firm in 1998 or in 1999 (that is, if the firm has investment in plant and machinery greater than $R s .6 .5$ million but less than $R s .30$ million in 1998 or 1999) and is equal to zero otherwise. ${ }^{11}$ Firms that have SizeD ummy $1_{i}=1$ are therefore firms that comprise the treatment group for the initial policy phase of credit expansion. Firms that have SizeDummy $1_{i}=0$ are firms that comprise the control group. ${ }^{12}$ This control group comprises of firms that were already in the priority sector before 1998 (or older priority sector firms, i.e., those firms with investment in plant and machinery less than $R s .6 .5$ million) as also firms that were never in the priority sector (all other non-priority sector firms with investment in plant and machinery greater than $R s .30$ million). YearDummy $1_{t}$ is a dummy variable which equals 1 for the year 1999 and 2000 and 0 otherwise. The vector $\mathbf{X}_{i t}$ denotes the set of all control variables and includes the size of the firm and dummy variables that control for industry effects. ${ }^{13}$ The coefficient of interest in the aforementioned regression is the coefficient on the interaction term, $\beta_{3}$, which measures the differential impact post the policy change of enhanced access to credit for the newly defined priority sector firms compared to all firms that are not affected by the policy change (see section 4.2 for an interpretation of the interaction term for the case of the specific dependent variable that we use in our specification). The time period that we consider in this regression runs from $t=1994$ to $2000 .{ }^{14}$

\footnotetext{
${ }^{8}$ For notational convenience we suppress the industry indicator $j$.

${ }^{9}$ We define a firm as an exporting firm if it has exports of at least Rs. 1 million. At the current exchange rate this is equivalent to approximately $\$ 16,000$ USD.

${ }^{10}$ See the appendix for definitions of these variables. Note that sales in our paper refers to the total sales of the firm and not domestic sales.

${ }^{11}$ See the appendix for the definition of plant and machinery.

${ }^{12} \mathrm{We}$ are using the standard difference-in-differences specification where the dependent variable is a growth rate itself (and not a level variable). For the difference-in-differences specification above, the coefficient of SizeDummy $1_{i}$ gives the difference in the growth rate of the variable of interest between treatment and control group firms in the pre-treatment period (or when $Y$ earDummy $1_{t}=0$ ) whereas the coefficient on YearDummy $1_{t}$ gives the difference in the growth rate of the variable of interest over pre and post treatment periods for the control group of firms (or when SizeDummy $1_{t}=0$ ). The coefficient on the interaction term SizeDummy $1_{i} * Y e a r D u m m y 1_{t}$ is the difference-in-differences estimator or a measure of the treatment effect. The difference-in-differences estimator gives the differential growth rate of treated firms compared to firms in the control group in the post-treatment period.

${ }^{13}$ To control for the fact that the bank might be providing more cash towards bigger firms we use the size of the firm (using log sales) as control. We also need to account for the fact that lending rules for bank officials specify lending constraints based on the actual (not projected) firm sales. Industry dummies control for sector specific effects-for example different sectors may have been subjected to different industrial policies.

${ }^{14}$ Recall that the reform was reversed in January 2000, so it did not affect credit decisions and availability post 2000.
} 
In our second step, we run the following difference-in-differences regression:

$$
\begin{aligned}
\ln (y)_{i t}-\ln (y)_{i t-1} & =\alpha_{0}+\sum_{t} \alpha_{t} \text { Time }_{t}+\beta_{1} \text { SizeDummy } 2_{i} \\
& +\beta_{2} \text { YearDummy } 2_{t}+\beta_{3} \text { SizeDummy } 2_{i} \times \text { YearDummy } 2_{t} \\
& +\mathbf{X}_{i t} \gamma+\varepsilon_{i t}
\end{aligned}
$$

where $y_{i t}$ represents the same set of variables as before. The time period covered by the above regression is now from $t=1999$ to 2005. SizeD ummy $2_{i}$ is a dummy variable that is equal to 1 if the firm is declassified as a priority sector firm in 2000, that is, if it has investment in plant and machinery greater than $R s .10$ million but less than $R s .30$ million in 2000 and is equal to 0 otherwise. YearDummy $2_{t}$ is a dummy variable which is equal 1 for the years 2001 to 2005 and 0 otherwise. The vector $\mathbf{X}_{i t}$ once again denotes the set of the same control variables as in equation 1, viz., the size of the firm and dummy variables that control for industry effects. The coefficient of interest is the coefficient on the interaction term, $\beta_{3}$, which measures the differential impact of this policy reversal on the declassified priority sector firms compared to all the firms that are not affected by this latest policy change (this control group comprises of firms with an investment in plant and machinery greater than $R s .30$ million as well as firms with an investment in plant and machinery of less than $R s .10$ million).

We note here that we also test the robustness of our main results from equations 1 and 2 earlier to different control group specifications. For example, for the credit expansion phase, our control group comprises of firms that were already in the priority sector before 1998 and also firms that were never in the priority sector. These are two different groups of firms. The already priority sector firms have investment in plant and machinery less than $R s .6 .5$ million while firms that were never in the priority sector have investment in plant and machinery greater than $R s .30$ million. To check the robustness of our results we therefore run regression 1 with these two different control groups of firms (for details see section 4.3.2). Again, recall that the control group for the credit contraction phase of the policy change comprises of firms removed from the priority sector. These include both smaller size firms with an investment in plant and machinery less than $R s .10$ million and also the larger firms with an investment in plant and machinery greater than $R s .30$ million. Again, we check the robustness of our results for the credit contraction phase by running regression 2 with these these two different groups of firms (for details see section 4.4.1). We also note here that our dependent variable is itself the growth rate of a variable. The "standard" difference-in-differences specification allows for levels of the dependent variable to be different for treatment and control groups. It requires that the trends in treatment and control groups be the same. In our case, since the dependent variable is itself a growth rate we require the trends in the growth rates for treatment and control group firms to be the same. This is a much weaker identification requirement since a-priori there is no reason to believe that the growth rates for treatment and control group firms should be any different. (for details see section 4.2). This is important since our main result involves comparing a treatment group with control groups that comprise of very different groups of firms.

Before we present our results, it is important to discuss the possible behavior of credit constrained firms vis-a-vis unconstrained firms in response to these policy changes. As discussed in Bannerjee and Duflo [2014], when new firms are classified as priority sector firms, then both constrained and unconstrained firms would be willing to absorb more credit if it is cheaper than other existing sources of credit. However, a constrained firm will use this credit primarily to expand output/sales whereas an unconstrained firm will use this credit primarily as a substitute for other more expensive sources of credit. An opposite set of conclusions holds for the credit contraction phase of the policy change. As a result, for unconstrained firms, we should see a much larger effect of the policy change on the profitability of the firm while we should see little or no impact on the sales of the firm. In contrast, for constrained firms, we should see a substantial impact of the policy change on the sales (either domestic or foreign) of the firm. ${ }^{15}$

\footnotetext{
$15_{\text {The }}$ rationale for these results is straightforward. If a firm is credit constrained then by definition, the marginal product of capital is higher than the rate of interest on the marginal amount borrowed. If such a firm is offered credit that is cheaper than the ongoing market
} 
4.2. Identification Issues. We now note some issues with the regression specifications 1 and 2 vis-a-vis identification. First, note that the policy change was exogenous at least with respect to our main variable of interest - exports. The policy was not implemented or targeted at exporting firms specifically. That is the thrust of the policy was not to increase export earnings of firms. So the treatment could be considered as exogenous at least for our main outcome variable. ${ }^{16}$ Moreover, as the criterion for priority sector lending was based on the plant and machinery in the firm, it was also not possible for firms to sort themselves below the threshold and get subsidized credit. Second, the dependent variable in our specification in equations 1 and 2 is itself a growth rate (unlike in conventional difference-in-differences specifications where the dependent variable is usually in levels). Our formulation is similar to the specification used in Bannerjee and Duflo [2014] who posit a simple parametric model where the estimation strategy involves estimating the difference in variable growth rates between treatment and control group firms pre and post treatment. Therefore in our specification, the coefficients of the interaction terms $\beta_{3} S i z e D u m m y 1_{i} \times$ YearDummy $1_{t}$ and $\beta_{3}$ SizeDummy $2_{i} \times$ YearDummy $2_{t}$ in equations 1 and 2 measure the difference in the growth rates of the variable $y$ between treatment and control group firms pre and post treatment (or what Bannerjee and Duflo [2014] call a "triple difference"). We note that for the specification given in 1 and 2 the identification assumption is that in the absence of treatment or the policy change there are no differential changes in the growth rates for treatment and control firms (which can happen if treatment group firms would have grown faster anyway, for example). So the assumption underlying our identification strategy is that treated firms would have the same trends for the growth rates of the variables under study had they not been treated. The counterfactual trend for the treatment group (or the counterfactual growth rate in our case) is of course never observed. The best that we can do in this case is to show the trend in the growth rates for different variables in the pre-treatment period to strengthen identification.

So to this end we show plots of the growth rates of treatment and control group firms in the pretreatment period for major variables of interest, viz., sales and exports. These are average growth rates for the treatment and control group firms for each year for these two variables. We also show the numerical values of the growth rates for these two variables in the plots itself.

\section{[Insert figure 1]}

For our two key variables of interest, sales and exports, we show plots of these variables in figure 1. Before we discuss figure 1, recall the definition of treatment and control group of firms in each phase of the policy change. Recall that for the credit expansion phase of the policy change treated firms are firms with an investment between $R s .6 .5$ to $R s .30$ million in 1998 which are the newly emergent priority sector firms and control group comprises of all other firms. Recall also that for the credit contraction phase of the policy change treated firms are firms with an investment in plant and machinery between $R s .10$ to $R s .30$ million in 2000 which are the firms that are removed from the priority sector and all other firms are in the control group. We note that the treatment group during the credit contraction phase of the policy change (which comprises of firms that were removed from the priority sector or firms with an investment in plant and machinery between $R s .10$ to $R s .30$ million) comprises a large fraction of the firms that are treated

rate, the firm will use this credit to invest in capital until the marginal rate of capital is equal to the interest rate. In contrast, a firm that is not credit constrained will use this cheap credit to payoff its outstanding debts.

${ }^{16}$ Priority sector lending has a long history going back to the time right after India's independence with the setup of the Reserve Bank of India (RBI) in 1951. The RBI is the central bank of the country and it also has the remit for priority sector lending. The RBI directs changes in priority sector lending with a goal to make credit accessible and thereby help in general development. The RBI has made continued efforts to facilitate availability of credit to specific sectors of the economy deemed to be in need of credit. Since independence the thrust of the RBI (and of successive governments in India at the center) in facilitating credit access has been evident in the policies pursued by the RBI (and the government). These policies include nationalization of banks (in two waves - one in 1969 and another in 1980), increasing the breadth and scope of the banking sector (for example, by requiring branches to be set up in rural parts of the country), etc. The policies that we are concerned with in our paper are a natural continuation of the efforts of the RBI (and of successive Indian governments) to provide (a pre-allotted portion of banks') funds to a few specific sectors (including among other sectors, micro and small scale enterprises). Keeping these facts in mind we are very skeptical if these policies were designed specifically for export promotion allaying any concerns regarding endogeneity for our main outcome of interest - exports. We also note that the work by Bannerjee, Cole, and Duflo [2004] is based on the very same (quasi) natural experiment. 
during the credit expansion part of the policy change (firms that have an investment between $R s .6 .5$ to $R s .30$ million). Therefore, there is a sizeable overlap in the treatment groups in the two phases of the policy change.Only firms with an investment in plant and machinery between $R s .6 .5$ to $R s$. 10 million which were treated in the credit expansion phase are excluded from the treatment group in the credit contraction phase. In other words the much larger fraction of firms or firms with investment in plant and machinery between $R s .10$ to $R s .30$ million are treated firms during both the credit expansion as well as the credit contraction phase. These group of firms get an injection of credit during the credit expansion phase and a subsequent reduction in cheap credit during the credit contraction phase.

Keeping in mind the considerable overlap of the treatment groups during both phases of the policy change let us now consider figure 1 . A cursory look at figure 1 , establishes visually that while the growth path of major variables is not exactly parallel for all of the variables the general trend for treatment and control groups is the same pre-treatment. In figure 1 the graphs show convincing evidence of parallel movement in the pre-treatment period for treated and control group firms for the major real variables of interest - sales and exports. We also note that figure 1 indicates (given our considerable overlap of treatment groups in the two phases of the policy change) that we can rule out the possibility that the difference in results that we obtain between the credit expansion and credit contraction phases of the policy change does not stem from the fact that the treated group (treated during the initial phase of the policy change) was growing at a faster rate than other control groups during any of the periods under consideration.

\subsection{Policy Change 1998.}

4.3.1. Effects of Credit Expansion. The result of the impact of the credit expansion phase of the policy change is reported in table 2 .

\section{[Insert table 2]}

We focus attention on the interaction term which is the difference-in-differences estimate (recall that in our case this is a growth rate difference). We find from table 2 that the coefficient of the interaction term is positive and significant for a number of specifications. For the variables representing various types of borrowing (the first two columns) the coefficient of the positive interaction term with high point estimates indicates that relative to firms in the control group, firms in the treatment group enjoyed a higher growth of bank borrowing. On average, the rate of growth of short-term bank borrowing for newly emergent priority sector firms increased by approximately 17 percent (relative to control group firms) following the policy change in 1998. Total bank borrowing of these firms increased by around 20 percent. ${ }^{17}$ We also find that the policy change in 1998 had no effect on the rate of growth of sales of the firm. ${ }^{18}$ Our key result is the impact of the policy change on the rate of growth of exports. We find that the growth rate of exports for treated firms increased by approximately 24 percent compared to the growth rate for control group firms. So, the major impact of the enhanced access to credit for exporting firms was on the exports of these firms. This is an important result. Exporting firms have to incur large sunk costs to break into export markets which have to be paid up front. ${ }^{19}$ We observe that the growth in credit is matched by a growth

\footnotetext{
${ }^{17}$ As Bannerjee and Duflo [2014] point out, lending to smaller clients is more costly and so ex-ante one should expect that banks would be saving on the cost of the cost of lending if they shifted their lending to the larger firms that newly became part of the priority sector. Of course, post reform the banks could be more selective in their choice of clients to fill in their priority sector quota. For both of these reasons the new members in the priority sector (or our treatment of firms) should by receiving more credit relative to firm already in the priority sector.

${ }^{18}$ We note that the coefficient on sales has the correct sign but is not statistically significant. We note that sales in our paper refers to total sales and not domestic sales. It might be interesting (and we thank an anonymous referee for pointing this out) to look only at domestic sales instead of total sales since domestic sales are arguably not dependent on the supply of credit while foreign (and by extension total sales) are. Unfortunately, CMIE does not provide data on (exclusively) domestic sales.

${ }^{19}$ See the empirical literature, for example, Roberts and Tybout [1995] for an example of hysteresis effects in export markets. Note that we are looking at the intensive margin where working capital is more important. The firms that are exporters have already managed to break into export markets (they changed the extensive margin when they entered the export market) and to do that they would likely have
} 
in exports - a clear indication of credit constrained behaviour. So our results would suggest that even for firms that have successfully broken into export markets, credit is still constrained. The (arguably) exogenous variation in credit to exporting firms results in higher sales growth of these firms in foreign markets. We also note that the coefficient on the interest payment (column 3) is not significant, which is expected since subsidized credit is not offered to firms at lower interest rates, so interest payments from firms should not change. ${ }^{20}$

4.3.2. Alternative Control Groups : Credit Expansion. We check the robustness of our results for the credit expansion phase of the policy change. These robustness exercises are described below. As our first exercise, we check the robustness of our results to alternative control groups during the credit expansion phase of the policy change. As mentioned earlier in section 4, the control group for the specification in regression 1 reported in table 2 comprises of firms that that were already in the priority sector (the older priority sector firms, i.e., those firms with investment in plant and machinery less than $R s .6 .5$ million) and also firms that were never in the priority sector (all other non-priority sector firms with investment in plant and machinery greater than $R s .30$ million). These two groups of firms have different firm characteristics which might lead the policy changes to have different impact on firms outcomes. So we repeat our difference-in-differences exercise with different control groups of firms (with the same treatment group of firms).

We now consider regression 1 but now only with the sample of firms that were always in the priority sector as our control group. These firms are small sized firms with investment in plant and machinery less than $R s .6 .5$ million. The result of this regression with this new control group is reported table 2 under the header "Only small firms as control". The results in table 2 with only small firms as control shows once again a positive differential growth rate for most of the financial variables for the newly emergent priority sector firms (although not all of these coefficients are significant at the conventional levels of significance). These results seem to suggest that compared to the small firms that were already in the priority sector newly emergent priority sector firms were also growing faster post-reform than pre-reform which reinforces the claim of credit constrained behaviour. Our most important result is the effect that the credit expansion has on the exports of the new priority sector firms. Once again we obtain a positive difference in the growth rates of exports between the treatment group of new priority sector firms and the (new) control group of firms that were always in the priority sector. So, newly emergent priority sector firms were having faster growth in real variables compared to the firms that were fortunate enough to be always in the priority sector.

Next, we once again restrict the sample size and now consider as a control group only those firms that were never in the priority sector. These are firms that had an investment in plant and machinery of more than $R s .30$ million. The result of this regression is reported in table 2 under the header "Only large firms as control". These results show a similar positive growth differential for newly emergent priority sector firms which suggests that during the credit expansion phase of the policy change newly emergent priority sector firms were growing faster than larger firms never in the priority sector. The signs of the coefficients on the interaction term for all variables is positive. We note in particular the positive coefficient on exports. Overall from the results table 2, we can conclude that our result of a positive effect on real firm outcomes for treatment group firms during the credit expansion part of the policy change is quite robust to alternative specifications involving different control groups of firms. ${ }^{21}$

to be financially sound (the extant literature has clearly linked breaking into export markets and financial strength) - and yet these same firms behave like they were credit constrained when they are offered priority credit. So it is surprising result that even firms that manage to break into export markets incurring considerable sunk costs still face such working capital constraints later.

${ }^{20}$ It may be argued here that if credit has expanded then interest payments must also expand. However, the likely reason for not finding this result is because the firms have partly substituted the more expensive credit with now the relatively cheaper credit from the banks (even though the banks offered the same interest rate) and also expanded their credit from banks. As a result the overall interest payments might not change even though the firms are borrowing lot more, because interest payments include all the interest payments.

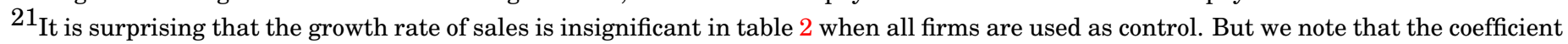
on sales growth is significant once only large firms are included as the control group. 
4.4. Policy Change 2000. In 2000 , some of the firms that were previously classified as priority sector in 1998 were removed from the priority sector. Now the banks were no longer required to provide directed lending under the priority sector regulation to these declassified firms (firms with an investment in plant and machinery between $R s .10$ and $R s .30$ million). However, the bank was free to renegotiate the terms of contract (credit limit and the interest rates) with these firms. The key implication of this policy change was that banks could now either reduce the credit limit to these firms or maintain the same credit limit depending on the firm's performance.

The results of the regression for the credit contraction phase are reported in table 3 under the header "All firms as control". ${ }^{22}$

\section{[Insert table 3 ]}

The results in table 3 suggest that (surprisingly) compared to the credit expansion phase in 1998, the policy reversal in 2000 had a far lesser impact on the growth of (total or short term) bank borrowings of the affected firms when compared with firms that remained in the priority sector. Most of the coefficients in table 3 are insignificant (at the conventional 1 percent and 5 percent level) other than the coefficients on total and short term borrowing which is expected. However, the policy change had little impact on the rate of growth of sales or on exports of the firm compared to the growth rate of control group firms. In fact, the coefficient on sales in table 3 shows a growth differential of only 3 percent (and it is not statistically significant) while exports are reduced by 6 percent (once again not significant). Unlike the results in the credit expansion phase of the policy change (reported in table 2) none of the coefficients on the real variables are statistically significant. So there is no clear effect of the credit contraction either on domestic firm sales or on the exports of firms that were removed from the priority sector. We note again that this result is different from those obtained in Bannerjee and Duflo [2014].

These results show that the effects of the credit contraction phase of the policy change are quite different from what we would expect a-priori - removal of firms from the priority sector does not seem to affect either the credit given to these firms or firm outcomes like sales or exports. Our explanation for this result is the following. As discussed earlier, the Indian banking system is characterized by under-lending primarily due to the rigid lending policies, inertia and the fear of prosecution by public loan officers. In 1998, after the change in the definition of SSI, the banks were compelled under the priority sector regulation to increase their limits to the newly classified priority sector firms. As a result of this enhanced access to credit, firms were able to grow rapidly and increase their turnover (as measured by the growth in the turnover of these firms). However, in 2000, when these firms were declassified as priority sector firms, the banks still followed their stringent lending policy but given the performance of the firms, there was no reason for the loan officers to reduce the growth of credit to such firms and hence no slowing down of real growth rates. Thus the subsequent policy change in 2000 had little or no impact on the firms that were declassified as priority sector.

4.4.1. Alternative Control Groups : Credit Contraction. We repeat our robustness exercise for the credit expansion phase of the policy change also for the credit contraction phase of the policy change. We recall that the control group in the regression given by specification 2 earlier comprises of smaller size firms with an investment in plant and machinery less than $R s .10$ million as also the larger firms with an investment in plant and machinery greater than $R s .30$ million that were never in the priority sector. Following our earlier exercise in which we limited the samples for the credit expansion phase of the policy change to allow for different control groups, we now follow a similar exercise for the credit contraction phase of the policy change. We now consider as robustness check regression 2 with different control groups. First, we consider as a control group firms with an investment in plant and machinery less than $R s .10$ million (note that this control group does not comprise of only firms that were always part of the

${ }^{22}$ When considering the size dummy for the credit contraction phase, we always consider firm size in the year of the policy change which is 2000. This ensures that we have a consistent group of firms for treatment and control. 
priority sector). These results are reported in table 3 under the header "Small firms as control". These results show a negative (but insignificant) growth differential for firms that are removed from the priority sector compared with the new control group of firms (which are firms with an investment in plant and machinery below $R s .10$ million). These results are broadly in agreement with the results in table 3 with all firms as control, but the magnitude of the differentials between treatment and control growth rates are larger. Next, we restrict the sample size again and consider only large sized firms that were never in the priority sector as the control group. These are firms that had investment in plant and machinery of more than $R$ s. 30 million. The result of this regression is reported under the header "Large firms as control" in table 3. These results also show negative differentials for firms that are removed from the priority sector (compared with firms with an investment in plant and machinery greater than $R s .30$ million as control) but the magnitudes of these differentials are lower than the case when all firms are used as control but are comparable with the magnitudes of the differential obtained with only small firms as control. Overall our results during the credit contraction phase of the policy change have a consistent sign over alternative specifications involving different control groups of firms.

\subsection{Additional Robustness Tests : Regressions involving unlisted firms. We check the robustness} of our results by limiting our sample to unlisted firms only. We note that the Prowess data base includes information on unlisted companies also (and is not limited to only firms listed in the stock exchange). Unlisted companies include public limited companies and private limited companies. We note that information on these unlisted companies, particularly private limited companies, is not easily available. However, CMIE makes its best efforts to include as many public and private limited companies as possible. This makes our sample representative since listed firms typically tend to be the bigger and more well-established firms. ${ }^{23}$ So our sample of firms is a representative sample of Indian manufacturing firms in general. However, as a robustness check we re-run all our regression specifications using a sub-sample of only unlisted firms. ${ }^{24}$ We consider three different control groups of firms as we did for our full sample (where we had both listed and unlisted firms as given in table 2) and the same treatment group. These results are reported in table 4 for the credit expansion phase of the policy change. Our results from the restricted sub-sample of unlisted firms are in general agreement with the results that we present in this paper with the full sample of firms. Importantly, the coefficient on exports is positive and significant for the case when all firms are used as control and also for the case when only large firms are used as control.

[Insert table 4 ]

Next we repeat our regressions for unlisted firms with different control groups for the credit contraction phase of the policy change and these results are reported table 5 .

[Insert table 5 ]

Once again the results for the credit contraction phase of the policy change for unlisted firms are in agreement with the results in table 3 . We find little evidence to indicate that the reduction in credit affected the unlisted firms adversely.

\section{CONCLUSiON}

In this paper, we contribute to the empirical literature on export-finance linkage. In particular, we study the causal impact of credit constraints on exporting firms by exploiting two policy changes in India that affected the availability of subsidized credit to some firms. The first policy change which took place in 1998 classified some firms as priority sector and made them eligible for subsidized credit lending from the

\footnotetext{
${ }^{23}$ In our correspondence with CMIE it has been communicated to us that “...The Prowess database covers all Indian companies for which relevant data became available to CMIE without any restrictions of use. Companies included in Prowess are not selected or filtered by any process." So the Prowess Prowess aims to cover all business entities for which reasonably reliable structured information is available.

${ }^{24}$ Once again we consider only exporting firms in these regressions.
} 
banks. We find evidence to indicate that the affected firms were credit constrained and the policy change which relaxed the credit constraints had a positive impact on the rate of growth of exports of the affected firms compared to growth rate of control group firms. However in 2000, when this policy was reversed and some of the firms were declassified as priority sector firms, there was little effect on the rate of growth of bank borrowing and almost no change in the rate of growth of exports for these firms. This finding suggests that once the bank-firm relationship was developed in terms of credit limit, there was no reason for the bank to renegotiate the terms of the credit as long as the firm had not defaulted. Our results also highlight the nature of lending by the Indian banking sector that is dominated by the public sector banks. Indian banks are characterized by under-lending primarily because the loan officers are not incentivized for good lending but they are penalized very heavily if the loans go bad. Perhaps the policy change in 1998 "nudged" the Indian banks to increase their exposure to the smaller firms which allowed the firms to grow rapidly and as long as the firms did not default, there was no reason for the banks to reduce the credit even when the policy was reversed and the firms were declassified as priority sector firms. This is an issue which needs further investigation. 
TABLE 1. Summary Statistics : Variables in Levels $(1994-2005){ }^{\dagger}$

\begin{tabular}{lccc}
\hline Variable & Mean & Std. Dev. & N \\
\hline \hline Short term Bank Borrowings & 10.466 & 69.541 & 30808 \\
Total Bank Borrowings & 12.906 & 83.334 & 40896 \\
Plant and Machinery & 45.279 & 342.956 & 40896 \\
Sales & 93.597 & 926.027 & 40896 \\
Exports & 8.231 & 72.699 & 40896 \\
Interest Expenses & 4.241 & 22.246 & 33065 \\
\hline \multicolumn{4}{|}{${ }^{\dagger}$ All figures in the above table are in Indian Rupees (INR). } \\
$\quad$ See the Appendix for definitions of the variables. \\
\hline
\end{tabular}




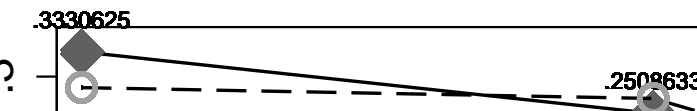

C .2852593

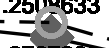

(4)

范

0
$i$

1996

1997

Year

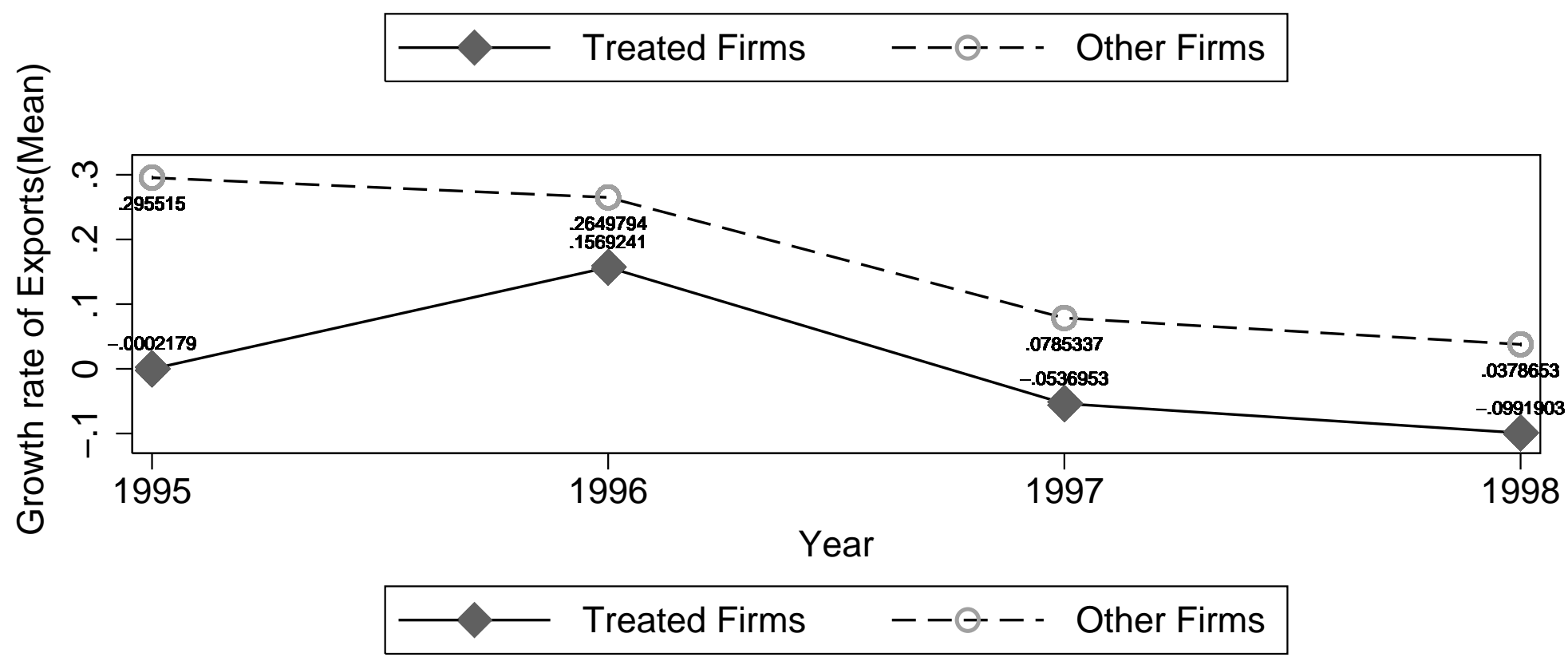

FIGURE 1. Yearly plot of real variable growth rates. Evidence of parallel trends. The figure shows the average yearly growth rates in the pre-treatment period (treatment takes place in 1998) for real outcome variables - sales and exports. Treated firms are firms with investment in plant and machinery between Rs.10 to Rs. 30 million. These firms are treated during the credit expansion phase of the policy change in 1998 when they receive subsidized credit and again in 2000 when they are removed from the priority sector. All other firms are in the control group. Note that firms with investment in plant and machinery between Rs.6.5 to Rs. 10 million which were treated during the credit expansion phase as not all these firms are removed from the priority sector during the credit contraction phase. 
TABLE 2. Credit Expansion ${ }^{\dagger}$

\begin{tabular}{|c|c|c|c|c|c|}
\hline & \multicolumn{3}{|c|}{ Financial } & \multicolumn{2}{|c|}{ Real } \\
\hline & $\begin{array}{l}\text { Bank } \\
\text { Borrowing }\end{array}$ & $\begin{array}{c}\text { Short-term } \\
\text { Bank Borrowing }\end{array}$ & $\begin{array}{l}\text { Interest } \\
\text { Payments }\end{array}$ & Sales & Exports \\
\hline \multicolumn{6}{|l|}{ All firms as control } \\
\hline$\ddagger$ SizeDummy1*YearDummy1 & $\begin{array}{l}0.203^{* *} \\
(0.068)\end{array}$ & $\begin{array}{l}0.169^{*} \\
(0.074)\end{array}$ & $\begin{array}{c}0.022 \\
(0.042)\end{array}$ & $\begin{array}{c}0.056 \\
(0.041)\end{array}$ & $\begin{array}{c}0.238 * * * \\
(0.067)\end{array}$ \\
\hline SizeDummy1 & $\begin{array}{l}-0.014 \\
(0.028)\end{array}$ & $\begin{array}{l}-0.023 \\
(0.038)\end{array}$ & $\begin{array}{l}-0.016 \\
(0.034)\end{array}$ & $\begin{array}{c}-0.046+ \\
(0.026)\end{array}$ & $\begin{array}{c}-0.133^{* *} \\
(0.044)\end{array}$ \\
\hline YearDummy1 & $\begin{array}{l}-0.124 * * * \\
(0.030)\end{array}$ & $\begin{array}{c}-0.103^{* *} \\
(0.030)\end{array}$ & $\begin{array}{c}-0.168^{* * * *} \\
(0.021)\end{array}$ & $\begin{array}{c}-0.065^{* *} \\
(0.020)\end{array}$ & $\begin{array}{c}-0.156 * * * \\
(0.031)\end{array}$ \\
\hline Log Sales & $\begin{array}{l}-0.001 \\
(0.004)\end{array}$ & $\begin{array}{c}-0.011+ \\
(0.006)\end{array}$ & $\begin{array}{c}0.000 \\
(0.008)\end{array}$ & $\begin{array}{c}-0.004 \\
(0.007)\end{array}$ & $\begin{array}{c}-0.034 * * * \\
(0.007)\end{array}$ \\
\hline No. of Obvs. & 9083 & 7909 & 8371 & 9546 & 8799 \\
\hline \multicolumn{6}{|l|}{ Only small firms as control } \\
\hline$\ddagger \ddagger$ SizeDummy $1 *$ YearDummy 1 & $\begin{array}{l}0.373^{*} \\
(0.175)\end{array}$ & $\begin{array}{c}0.233 \\
(0.189)\end{array}$ & $\begin{array}{c}-0.042 \\
(0.157)\end{array}$ & $\begin{array}{c}0.048 \\
(0.147)\end{array}$ & $\begin{array}{l}0.231^{*} \\
(0.108)\end{array}$ \\
\hline SizeDummy1 & $\begin{array}{l}-0.038 \\
(0.068)\end{array}$ & $\begin{array}{l}-0.026 \\
(0.065)\end{array}$ & $\begin{array}{l}-0.008 \\
(0.044)\end{array}$ & $\begin{array}{c}-0.136^{* * *} \\
(0.036)\end{array}$ & $\begin{array}{l}-0.165^{*} \\
(0.081)\end{array}$ \\
\hline YearDummy1 & $\begin{array}{l}-0.314 \\
(0.213)\end{array}$ & $\begin{array}{l}-0.204 \\
(0.195)\end{array}$ & $\begin{array}{l}-0.048 \\
(0.170)\end{array}$ & $\begin{array}{l}-0.025 \\
(0.170)\end{array}$ & $\begin{array}{l}-0.271^{*} \\
(0.105)\end{array}$ \\
\hline Log Sales & $\begin{array}{l}0.006 \\
(0.027)\end{array}$ & $\begin{array}{c}-0.012 \\
(0.029)\end{array}$ & $\begin{array}{c}0.021 \\
(0.025)\end{array}$ & $\begin{array}{c}0.020 \\
(0.026)\end{array}$ & $\begin{array}{c}0.016 \\
(0.020)\end{array}$ \\
\hline No. of Obvs. & 920 & 786 & 864 & 1072 & 943 \\
\hline \multicolumn{6}{|l|}{ Only large firms as control } \\
\hline$\ddagger \ddagger \ddagger$ SizeDummy 1 *YearDummy 1 & $\begin{array}{l}0.211^{* *} \\
(0.077)\end{array}$ & $\begin{array}{l}0.187^{*} \\
(0.077)\end{array}$ & $\begin{array}{c}0.046 \\
(0.041)\end{array}$ & $\begin{array}{c}0.075+ \\
(0.043)\end{array}$ & $\begin{array}{c}0.277 * * * \\
(0.065)\end{array}$ \\
\hline SizeDummy1 & $\begin{array}{l}-0.036 \\
(0.039)\end{array}$ & $\begin{array}{l}-0.055 \\
(0.044)\end{array}$ & $\begin{array}{l}-0.045 \\
(0.034)\end{array}$ & $\begin{array}{l}-0.062^{*} \\
(0.026)\end{array}$ & $\begin{array}{c}-0.185^{* * *} \\
(0.041)\end{array}$ \\
\hline YearDummy1 & $\begin{array}{l}-0.123^{* * *} \\
(0.031)\end{array}$ & $\begin{array}{c}-0.103^{* *} \\
(0.030)\end{array}$ & $\begin{array}{c}-0.169 * * * \\
(0.021)\end{array}$ & $\begin{array}{c}-0.069 * * \\
(0.020)\end{array}$ & $\begin{array}{c}-0.155^{* * * *} \\
(0.031)\end{array}$ \\
\hline Log Sales & $\begin{array}{l}-0.003 \\
(0.005)\end{array}$ & $\begin{array}{c}-0.013^{*} \\
(0.006)\end{array}$ & $\begin{array}{c}-0.003 \\
(0.008)\end{array}$ & $\begin{array}{c}-0.005 \\
(0.007)\end{array}$ & $\begin{array}{c}-0.038^{* * * *} \\
(0.007)\end{array}$ \\
\hline No. of Obvs. & 8911 & 7764 & 8206 & 9318 & 8596 \\
\hline
\end{tabular}

$\dagger$ Each column represents the dependent variable in a regression on SizeDummy1, YearDummy1 and SizeDummy1*YearDummy1(the difference-in-differences estimator). All regressions include time dummies and control for firm size using log sales as control. The time period covered by this regression is from 1994 to 2000.

¥ The treatment group comprises of firms with investment in plant and machinery between Rs. 6.5 million and Rs. 30 million in 1998 or in 1999 which newly became part of priority sector and the control group comprises of firms with investment in plant and machinery below Rs. 6.5 million which were always part of priority sector and firms with investment in plant and machinery greater than Rs. 30 million which were never part of priority sector.

$\ddagger \ddagger$ The treatment group comprises of firms with investment in plant and machinery between Rs. 6.5 million and Rs. 30 million in 1998 or in 1999 which newly became part of priority sector and the control group comprises of firms with investment in plant and machinery below Rs. 6.5 million which were always part of priority sector.

$\ddagger \ddagger \ddagger$ The treatment group comprises of firms with investment in plant and machinery between Rs. 6.5 million and Rs. 30 million in 1998 or in 1999 which newly became part of priority sector and the control group comprises of firms with investment in plant and machinery above Rs. 30 million which were never part of the priority sector.

$\S$ Note : $t$-statistics reported under each coefficient in parenthesis. Significance at $:^{+} p<0.10^{*} p<0.05,{ }^{* *} p<0.01,{ }^{* * *} p<0.001$. Standard errors are clustered at the (3-digit) industry level. 
TABLE 3. Credit Contraction ${ }^{\dagger}$

\begin{tabular}{|c|c|c|c|c|c|}
\hline & \multicolumn{3}{|c|}{ Financial } & \multicolumn{2}{|c|}{ Real } \\
\hline & $\begin{array}{l}\text { Bank } \\
\text { Borrowing }\end{array}$ & $\begin{array}{c}\text { Short-term } \\
\text { Bank Borrowing }\end{array}$ & $\begin{array}{l}\text { Interest } \\
\text { Payments }\end{array}$ & Sales & Exports \\
\hline \multicolumn{6}{|l|}{ All firms as control } \\
\hline ‡ SizeDummy2*YearDummy2 & $\begin{array}{l}-0.144^{*} \\
(0.065)\end{array}$ & $\begin{array}{c}-0.141+ \\
(0.070)\end{array}$ & $\begin{array}{c}0.053 \\
(0.053)\end{array}$ & $\begin{array}{c}-0.033 \\
(0.037)\end{array}$ & $\begin{array}{c}-0.066 \\
(0.070)\end{array}$ \\
\hline SizeDummy2 & $\begin{array}{l}0.197 * * * \\
(0.056)\end{array}$ & $\begin{array}{l}0.186 * * \\
(0.057)\end{array}$ & $\begin{array}{c}0.044 \\
(0.049)\end{array}$ & $\begin{array}{l}0.089^{*} \\
(0.035)\end{array}$ & $\begin{array}{l}0.174 * * \\
(0.055)\end{array}$ \\
\hline YearDummy2 & $\begin{array}{l}0.018 \\
(0.033)\end{array}$ & $\begin{array}{l}-0.038 \\
(0.031)\end{array}$ & $\begin{array}{c}-0.082^{* * * *} \\
(0.017)\end{array}$ & $\begin{array}{l}-0.034^{*} \\
(0.016)\end{array}$ & $\begin{array}{l}0.052^{*} \\
(0.023)\end{array}$ \\
\hline Log Sales & $\begin{array}{l}0.005 \\
(0.005)\end{array}$ & $\begin{array}{c}0.002 \\
(0.006)\end{array}$ & $\begin{array}{c}0.019 * * * \\
(0.005)\end{array}$ & $\begin{array}{c}0.037 * * * \\
(0.004)\end{array}$ & $\begin{array}{l}0.019^{*} \\
(0.009)\end{array}$ \\
\hline No. of Obvs. & 9352 & 8097 & 8834 & 10289 & 9616 \\
\hline \multicolumn{6}{|l|}{ Only small firms as control } \\
\hline$\ddagger \ddagger$ SizeDummy $2 *$ YearDummy2 & $\begin{array}{l}-0.265+ \\
(0.152)\end{array}$ & $\begin{array}{l}-0.235 \\
(0.181)\end{array}$ & $\begin{array}{c}-0.121 \\
(0.094)\end{array}$ & $\begin{array}{c}-0.030 \\
(0.123)\end{array}$ & $\begin{array}{l}-0.272^{*} \\
(0.111)\end{array}$ \\
\hline SizeDummy2 & $\begin{array}{l}0.169 \\
(0.160)\end{array}$ & $\begin{array}{c}0.148 \\
(0.167)\end{array}$ & $\begin{array}{c}0.041 \\
(0.077)\end{array}$ & $\begin{array}{l}-0.077 \\
(0.102)\end{array}$ & $\begin{array}{l}0.246^{*} \\
(0.118)\end{array}$ \\
\hline YearDummy2 & $\begin{array}{l}0.113 \\
(0.175)\end{array}$ & $\begin{array}{c}0.145 \\
(0.197)\end{array}$ & $\begin{array}{l}-0.001 \\
(0.096)\end{array}$ & $\begin{array}{l}-0.127 \\
(0.145)\end{array}$ & $\begin{array}{l}0.202^{*} \\
(0.094)\end{array}$ \\
\hline Log Sales & $\begin{array}{l}0.048+ \\
(0.028)\end{array}$ & $\begin{array}{c}0.057^{*} \\
(0.023)\end{array}$ & $\begin{array}{l}0.057^{*} \\
(0.022)\end{array}$ & $\begin{array}{c}0.055^{* * *} \\
(0.012)\end{array}$ & $\begin{array}{c}0.032 \\
(0.023)\end{array}$ \\
\hline No. of Obvs. & 643 & 557 & 627 & 838 & 738 \\
\hline \multicolumn{6}{|l|}{ Only large firms as control } \\
\hline$\ddagger \ddagger \ddagger$ SizeDummy $2 *$ YearDummy2 & $\begin{array}{l}-0.127+ \\
(0.067)\end{array}$ & $\begin{array}{c}-0.129+ \\
(0.071)\end{array}$ & $\begin{array}{c}0.060 \\
(0.054)\end{array}$ & $\begin{array}{l}-0.027 \\
(0.037)\end{array}$ & $\begin{array}{l}-0.054 \\
(0.077)\end{array}$ \\
\hline SizeDummy2 & $\begin{array}{l}0.182^{* *} \\
(0.061)\end{array}$ & $\begin{array}{c}0.179 * * \\
(0.061)\end{array}$ & $\begin{array}{c}0.044 \\
(0.049)\end{array}$ & $\begin{array}{c}0.096 * * \\
(0.036)\end{array}$ & $\begin{array}{l}0.170^{*} \\
(0.066)\end{array}$ \\
\hline YearDummy2 & $\begin{array}{l}0.016 \\
(0.033)\end{array}$ & $\begin{array}{l}-0.042 \\
(0.032)\end{array}$ & $\begin{array}{c}-0.084^{* * * *} \\
(0.017)\end{array}$ & $\begin{array}{c}-0.027+ \\
(0.015)\end{array}$ & $\begin{array}{l}0.050^{*} \\
(0.024)\end{array}$ \\
\hline Log Sales & $\begin{array}{l}0.004 \\
(0.005)\end{array}$ & $\begin{array}{c}0.002 \\
(0.007)\end{array}$ & $\begin{array}{c}0.019 * * * \\
(0.005)\end{array}$ & $\begin{array}{c}0.039 * * * \\
(0.005)\end{array}$ & $\begin{array}{l}0.018+ \\
(0.009)\end{array}$ \\
\hline No. of Obvs. & 9191 & 7964 & 8679 & 10035 & 9392 \\
\hline
\end{tabular}

$\dagger$ Each column represents the dependent variable in a regression on SizeDummy2, YearDummy2 and SizeDummy2*YearDummy2 (the difference-in-differences estimator). All regressions include time dummies and control for firm size using log sales as control. The time period covered by this regression is from 1999 to 2005.

¥ The treatment group comprises of firms with investment in plant and machinery between Rs.10 million and Rs. 30 million in 2000 which were removed from the priority sector and the control group comprises of firms with investment in plant and machinery below Rs.10 million and firms with investment in plant and machinery greater than Rs. 30 million.

$\ddagger \ddagger$ The treatment group comprises of firms with investment in plant and machinery between Rs.10 million and Rs.30 million in 2000 which were removed from the priority sector and the control group comprises of firms with investment in plant and machinery below Rs.10 million.

$\ddagger \ddagger \ddagger$ The treatment group comprises of firms with investment in plant and machinery between Rs. 10 million and Rs. 30 million in 2000 which were removed from priority sector and the control group comprises of firms with investment in plant and machinery above Rs. 30 million.

$\S$ Note : $t$-statistics reported under each coefficient in parenthesis. Significance at $:^{+} p<0.10^{*} p<0.05,{ }^{* *} p<0.01,{ }^{* * *} p<0.001$. Standard errors are clustered at the (3-digit) industry level. 
TABLE 4. Credit Expansion : Unlisted Firms Only ${ }^{\dagger}$

\begin{tabular}{|c|c|c|c|c|c|}
\hline & \multicolumn{3}{|c|}{ Financial } & \multicolumn{2}{|c|}{ Real } \\
\hline & $\begin{array}{l}\text { Bank } \\
\text { Borrowing }\end{array}$ & $\begin{array}{c}\text { Short-term } \\
\text { Bank Borrowing }\end{array}$ & $\begin{array}{l}\text { Interest } \\
\text { Payments }\end{array}$ & Sales & Exports \\
\hline \multicolumn{6}{|l|}{ All firms as control } \\
\hline ‡SizeDummy1*YearDummy1 & $\begin{array}{l}0.177 \\
(0.122)\end{array}$ & $\begin{array}{c}0.073 \\
(0.134)\end{array}$ & $\begin{array}{l}-0.016 \\
(0.081)\end{array}$ & $\begin{array}{l}-0.005 \\
(0.046)\end{array}$ & $\begin{array}{l}0.255^{* *} \\
(0.083)\end{array}$ \\
\hline SizeDummy1 & $\begin{array}{l}0.041 \\
(0.035)\end{array}$ & $\begin{array}{c}0.038 \\
(0.058)\end{array}$ & $\begin{array}{c}0.043 \\
(0.047)\end{array}$ & $\begin{array}{c}0.014 \\
(0.038)\end{array}$ & $\begin{array}{l}-0.072 \\
(0.069)\end{array}$ \\
\hline YearDummy1 & $\begin{array}{l}-0.133^{* *} \\
(0.049)\end{array}$ & $\begin{array}{l}-0.018 \\
(0.050)\end{array}$ & $\begin{array}{c}-0.093^{* *} \\
(0.030)\end{array}$ & $\begin{array}{l}-0.033 \\
(0.032)\end{array}$ & $\begin{array}{c}-0.164^{* *} \\
(0.049)\end{array}$ \\
\hline Log Sales & $\begin{array}{l}0.004 \\
(0.009)\end{array}$ & $\begin{array}{c}-0.024+ \\
(0.013)\end{array}$ & $\begin{array}{c}0.008 \\
(0.014)\end{array}$ & $\begin{array}{c}0.009 \\
(0.010)\end{array}$ & $\begin{array}{l}-0.014 \\
(0.012)\end{array}$ \\
\hline No. of Obvs. & 2956 & 1937 & 2130 & 3166 & 2892 \\
\hline \multicolumn{6}{|l|}{ Only small firms as control } \\
\hline$\ddagger \ddagger$ SizeDummy1*YearDummy1 & $\begin{array}{l}0.362 \\
(0.274)\end{array}$ & $\begin{array}{c}0.188 \\
(0.263)\end{array}$ & $\begin{array}{l}-0.158 \\
(0.251)\end{array}$ & $\begin{array}{c}-0.118 \\
(0.171)\end{array}$ & $\begin{array}{c}0.217 \\
(0.137)\end{array}$ \\
\hline SizeDummy1 & $\begin{array}{l}0.093 \\
(0.114)\end{array}$ & $\begin{array}{c}0.053 \\
(0.103)\end{array}$ & $\begin{array}{c}0.066 \\
(0.093)\end{array}$ & $\begin{array}{l}-0.059 \\
(0.063)\end{array}$ & $\begin{array}{l}-0.091 \\
(0.111)\end{array}$ \\
\hline YearDummy1 & $\begin{array}{l}-0.334 \\
(0.244)\end{array}$ & $\begin{array}{l}-0.267 \\
(0.208)\end{array}$ & $\begin{array}{c}0.192 \\
(0.241)\end{array}$ & $\begin{array}{c}0.111 \\
(0.190)\end{array}$ & $\begin{array}{l}-0.152 \\
(0.128)\end{array}$ \\
\hline Log Sales & $\begin{array}{l}-0.020 \\
(0.045)\end{array}$ & $\begin{array}{c}-0.129 * * * \\
(0.030)\end{array}$ & $\begin{array}{l}-0.047 \\
(0.063)\end{array}$ & $\begin{array}{c}0.030 \\
(0.049)\end{array}$ & $\begin{array}{c}0.026 \\
(0.050)\end{array}$ \\
\hline No. of Obvs. & 336 & 223 & 261 & 400 & 351 \\
\hline \multicolumn{6}{|l|}{ Only large firms as control } \\
\hline $+\ddagger$ SizeDummy1*YearDummy1 & $\begin{array}{l}0.175 \\
(0.144)\end{array}$ & $\begin{array}{c}0.100 \\
(0.141)\end{array}$ & $\begin{array}{c}0.046 \\
(0.090)\end{array}$ & $\begin{array}{c}0.019 \\
(0.043)\end{array}$ & $\begin{array}{c}0.248^{* *} \\
(0.084)\end{array}$ \\
\hline SizeDummy1 & $\begin{array}{l}0.031 \\
(0.056)\end{array}$ & $\begin{array}{c}0.002 \\
(0.064)\end{array}$ & $\begin{array}{l}-0.020 \\
(0.054)\end{array}$ & $\begin{array}{c}0.007 \\
(0.039)\end{array}$ & $\begin{array}{l}-0.084 \\
(0.070)\end{array}$ \\
\hline YearDummy1 & $\begin{array}{l}-0.132 * \\
(0.050)\end{array}$ & $\begin{array}{l}-0.018 \\
(0.051)\end{array}$ & $\begin{array}{l}-0.100 * * \\
(0.030)\end{array}$ & $\begin{array}{l}-0.045 \\
(0.032)\end{array}$ & $\begin{array}{c}-0.169 * * * \\
(0.048)\end{array}$ \\
\hline Log Sales & $\begin{array}{l}0.001 \\
(0.011)\end{array}$ & $\begin{array}{c}-0.023+ \\
(0.012)\end{array}$ & $\begin{array}{c}0.002 \\
(0.012)\end{array}$ & $\begin{array}{c}0.006 \\
(0.010)\end{array}$ & $\begin{array}{c}-0.021+ \\
(0.012)\end{array}$ \\
\hline No. of Obvs. & 2889 & 1895 & 2077 & 3082 & 2818 \\
\hline
\end{tabular}

$\dagger$ Each column represents the dependent variable in a regression on SizeDummy1, YearDummy1 and SizeDummy1*YearDummy1(the difference-in-differences estimator). All regressions include time dummies and control for firm size using log sales as control. The time period covered by this regression is from 1994 to 2000. The estimation sample for results reported in this table comprises of firms that are not listed in the stock exchange or unlisted firms.

¥ The treatment group comprises of firms with investment in plant and machinery between Rs. 6.5 million and Rs. 30 million in 1998 or in 1999 which newly became part of priority sector and the control group comprises of firms with investment in plant and machinery below Rs. 6.5 million which were always part of priority sector and firms with investment in plant and machinery greater than Rs. 30 million which were never part of priority sector.

$\$$ The treatment group comprises of firms with investment in plant and machinery between Rs. 6.5 million and Rs. 30 million which newly became part of priority sector and the control group comprises of firms with investment in plant and machinery below Rs. 6.5 million which were always part of priority sector.

$\ddagger \ddagger$ The treatment group comprises of firms with investment in plant and machinery between Rs. 6.5 million and Rs. 30 million in 1998 or in 1999 which newly became part of priority sector and the control group comprises of firms with investment in plant and machinery above Rs. 30 million which were never part of the priority sector.

$\S$ Note : $t$-statistics reported under each coefficient in parenthesis. Significance at $:^{+} p<0.10^{*} p<0.05,{ }^{* *} p<0.01,{ }^{* * *} p<0.001$. Standard errors are clustered at the (3-digit) industry level. 
TABLE 5. Credit Contraction : Unlisted Firms Only ${ }^{\dagger \S}$

\begin{tabular}{|c|c|c|c|c|c|}
\hline & \multicolumn{3}{|c|}{ Financial } & \multicolumn{2}{|c|}{ Real } \\
\hline & $\begin{array}{l}\text { Bank } \\
\text { Borrowing }\end{array}$ & $\begin{array}{c}\text { Short-term } \\
\text { Bank Borrowing }\end{array}$ & $\begin{array}{l}\text { Interest } \\
\text { Payments }\end{array}$ & Sales & Exports \\
\hline \multicolumn{6}{|l|}{ All firms as control } \\
\hline$\ddagger$ SizeDummy2*YearDummy2 & $\begin{array}{l}-0.133 \\
(0.139)\end{array}$ & $\begin{array}{l}-0.156 \\
(0.165)\end{array}$ & $\begin{array}{c}0.020 \\
(0.105)\end{array}$ & $\begin{array}{c}0.033 \\
(0.054)\end{array}$ & $\begin{array}{l}-0.066 \\
(0.085)\end{array}$ \\
\hline SizeDummy2 & $\begin{array}{l}0.243+ \\
(0.125)\end{array}$ & $\begin{array}{c}0.247 \\
(0.159)\end{array}$ & $\begin{array}{c}0.105 \\
(0.103)\end{array}$ & $\begin{array}{c}0.044 \\
(0.053)\end{array}$ & $\begin{array}{c}0.125 \\
(0.078)\end{array}$ \\
\hline YearDummy2 & $\begin{array}{l}0.043 \\
(0.059)\end{array}$ & $\begin{array}{c}-0.081+ \\
(0.047)\end{array}$ & $\begin{array}{l}-0.074^{*} \\
(0.032)\end{array}$ & $\begin{array}{c}-0.047+ \\
(0.027)\end{array}$ & $\begin{array}{c}0.071 \\
(0.051)\end{array}$ \\
\hline Log Sales & $\begin{array}{l}-0.011 \\
(0.008)\end{array}$ & $\begin{array}{l}-0.004 \\
(0.010)\end{array}$ & $\begin{array}{l}0.024^{* *} \\
(0.008)\end{array}$ & $\begin{array}{c}0.042^{* * *} \\
(0.005)\end{array}$ & $\begin{array}{c}0.022 \\
(0.017)\end{array}$ \\
\hline No. of Obvs. & 3337 & 2235 & 2550 & 3791 & 3484 \\
\hline \multicolumn{6}{|l|}{ Only small firms as control } \\
\hline$\ddagger \ddagger$ SizeDummy2*YearDummy2 & $\begin{array}{l}-0.308 \\
(0.272)\end{array}$ & $\begin{array}{l}-0.142 \\
(0.295)\end{array}$ & $\begin{array}{l}-0.256 \\
(0.214)\end{array}$ & $\begin{array}{c}0.043 \\
(0.153)\end{array}$ & $\begin{array}{l}-0.220 \\
(0.175)\end{array}$ \\
\hline SizeDummy2 & $\begin{array}{l}0.458 \\
(0.326)\end{array}$ & $\begin{array}{c}0.319 \\
(0.297)\end{array}$ & $\begin{array}{c}0.132 \\
(0.177)\end{array}$ & $\begin{array}{l}-0.071 \\
(0.159)\end{array}$ & $\begin{array}{c}0.118 \\
(0.117)\end{array}$ \\
\hline YearDummy2 & $\begin{array}{l}0.200 \\
(0.204)\end{array}$ & $\begin{array}{c}0.121 \\
(0.207)\end{array}$ & $\begin{array}{l}-0.014 \\
(0.160)\end{array}$ & $\begin{array}{l}-0.173 \\
(0.158)\end{array}$ & $\begin{array}{c}0.116 \\
(0.112)\end{array}$ \\
\hline Log Sales & $\begin{array}{l}-0.069 \\
(0.053)\end{array}$ & $\begin{array}{l}-0.074 \\
(0.050)\end{array}$ & $\begin{array}{c}0.038 \\
(0.054)\end{array}$ & $\begin{array}{l}0.043+ \\
(0.024)\end{array}$ & $\begin{array}{c}0.029 \\
(0.032)\end{array}$ \\
\hline No. of Obvs. & 279 & 199 & 257 & 386 & 331 \\
\hline \multicolumn{6}{|l|}{ Only large firms as control } \\
\hline$\ddagger \ddagger \ddagger$ SizeDummy2*YearDummy2 & $\begin{array}{l}-0.113 \\
(0.142)\end{array}$ & $\begin{array}{l}-0.146 \\
(0.166)\end{array}$ & $\begin{array}{l}-0.007 \\
(0.112)\end{array}$ & $\begin{array}{c}0.032 \\
(0.054)\end{array}$ & $\begin{array}{l}-0.066 \\
(0.081)\end{array}$ \\
\hline SizeDummy2 & $\begin{array}{l}0.221+ \\
(0.125)\end{array}$ & $\begin{array}{c}0.236 \\
(0.158)\end{array}$ & $\begin{array}{c}0.145 \\
(0.097)\end{array}$ & $\begin{array}{c}0.052 \\
(0.054)\end{array}$ & $\begin{array}{c}0.137 \\
(0.086)\end{array}$ \\
\hline YearDummy2 & $\begin{array}{l}0.037 \\
(0.057)\end{array}$ & $\begin{array}{c}-0.088+ \\
(0.049)\end{array}$ & $\begin{array}{l}-0.072^{*} \\
(0.032)\end{array}$ & $\begin{array}{l}-0.032 \\
(0.025)\end{array}$ & $\begin{array}{c}0.078 \\
(0.051)\end{array}$ \\
\hline Log Sales & $\begin{array}{l}-0.012 \\
(0.008)\end{array}$ & $\begin{array}{l}-0.004 \\
(0.011)\end{array}$ & $\begin{array}{l}0.024^{* *} \\
(0.008)\end{array}$ & $\begin{array}{c}0.041^{* * *} \\
(0.006)\end{array}$ & $\begin{array}{c}0.022 \\
(0.018)\end{array}$ \\
\hline No. of Obvs. & 3252 & 2174 & 2470 & 3662 & 3371 \\
\hline
\end{tabular}

$\dagger$ Each column represents the dependent variable in a regression on SizeDummy2, YearDummy2 and SizeDummy2*YearDummy2 (the difference-in-differences estimator). All regressions include time dummies and control for firm size using log sales as control. The time period covered by this regression is from 1999 to 2005. The estimation sample for results reported in this table comprises of firms that are not listed in the stock exchange or unlisted firms.

¥ The treatment group comprises of firms with investment in plant and machinery between Rs.10 million and Rs.30 million in 2000 which were removed from the priority sector and the control group comprises of firms with investment in plant and machinery below Rs.10 million and firms with investment in plant and machinery greater than Rs.30 million.

$\ddagger \ddagger$ The treatment group comprises of firms with investment in plant and machinery between Rs. 10 million and Rs. 30 million in 2000 which were removed from priority sector and the control group comprises of firms with investment in plant and machinery below Rs. 10 million.

$\ddagger \ddagger \ddagger$ The treatment group comprises of firms with investment in plant and machinery between Rs. 10 million and Rs. 30 million in 2000 which were removed from priority sector and the control group comprises of firms with investment in plant and machinery above Rs. 30 million.

$\S$ Note : $t$-statistics reported under each coefficient in parenthesis. Significance at ${ }^{+} p<0.10^{*} p<0.05,{ }^{* *} p<0.01,{ }^{* * *} p<0.001$. Standard errors are clustered at the (3-digit) industry level. 


\section{Appendix}

Definitions. The following are definitions of variables used in the paper and are taken verbatim from the "Data Dictionary" accompanying the Prowess Database.

(1) Total Bank borrowing This is the total of loans sourced from banks. It includes loans from banks in the form of cash credit, bank overdraft facilities, term loans, etc.

(2) Sales is the sum of industrial sales and income from non-financial services.

(3) Short-term bank borrowings are bank loans having a maturity of less than a year. Usually, short-term bank borrowing accounts for 75-80 per cent of bank borrowings. All types of loans in the form of short-term loans, cash credits, bank overdrafts, etc. are treated at par and all are clubbed to show short-term bank borrowing.

(4) Export (earnings) is the total revenue/income earned from exports of goods.

(5) Plant and machinery refer to the plant and machinery used in producing goods and services or for rental to others. The identification of plant and machinery is a function of the nature of activity of the company.

(6) Variables in the paper

(a) SizeDummy1: The dummy SizeDummy1 is equal to 1 for firms with investment in plant and machinery between Rs 6.5 million and Rs 30 million in 1998 or in 1999 and 0 otherwise.

(b) YearDummy1: The dummy YearDummy1 is equal to 1 for the years 1999 and 2000 and 0 otherwise.

(c) SizeDummy2: The dummy SizeDummy2 is equal to 1 for firms with investment in plant and machinery between Rs.10 million - Rs.30 million in 2000 and 0 otherwise.

(d) YearDummy2: The dummy YearDummy2 is equal to 1 for the years 2001-2005 and 0 otherwise. 
Bannerjee, A., S. A. Cole, and E. Duflo (2004): "Banking Reform in India," Bureau for Research in Economic Analysis of Development, Policy Paper, 1(006), 277-323, Brookings Institution Press.

Bannerjee, A., And E. Duflo (2014): "Do Firms Want to Borrow More?Testing Credit Constraints Using a Directed Lending Program," Review of Economic Studies (2014), 81(2), 572607.

BECK, T. (2003): "Financial Dependence and International Trade," Review of International Economics, (11), 296-316.

Bernard, A., AND J. B. JENSEn (1999): "Exceptional Exporter Performance : Cause, Effect or Both?," Journal of International Economics, 47(1), 1-25.

CAMPA, J., AND J. SHAVER (2002): "Exporting and Capital Investment: On the Strategic Behavior of Exporters," IESE Business School, University of Navarra, Discussion Paper, (469).

Chaney, T. (2013): "Liquidity Constrained Exporters," Discussion paper, National Bureau of Economic Research.

EGGER, P., AND M. KESINA (2013): "Financial constraints and exports: evidence from Chinese firms," CESifo Economic Studies, 59(4), 676-706.

Feenstra, R. C., Z. LI, AND M. YU (2014): "Exports and credit constraints under incomplete information: Theory and evidence from China," Review of Economics and Statistics, 96(4), 729744.

Guariglia, A., AND S. MATEuT (2010): "Inventory Investment, Global Engagement and Financial Constraints in the U.K.: Evidence from Micro-Data," Journal of Macroeconomics, 32(1), 239-250.

KoKKo, A. (2002): Export-led growth in East Asia : Lessons from Europe's Transition Economies. National Europe Centre, Australian National University.

MANova, K. (2013): "Credit constraints, Heterogeneous Firms and International Trade," The Review of Economic Studies, 80(2), 711-744.

MELITZ, M. J. (2003): "The Impact of Trade on Intra-Industry Reallocations and Aggregate Industry Productivity," Econometrica, 71 (6), 1695-1725.

MinetTI, R., AND S. C. ZHU (2011): "Credit constraints and firm export: Microeconomic evidence from Italy," Journal of International Economics, 83(2), 109-125.

MUÛLS, M. (2008): "Exporters and Credit Constraints. A firm level approach,” Discussion paper, National Bank of Belgium, Working Paper.

PARAVISINI, D., V. RAPPOPORT, P. SCHNABL, AND D. WolfEnZON (2011): "Dissecting the Effect of Credit Supply on Trade: Evidence from Matched Credit-Export Data,” Working Paper 16975, National Bureau of Economic Research.

Reserve BANK of India CiRcular (2006): "RBI Master Circular," Discussion paper, Reserve Bank of India (RBI).

Roberts, M. J., AND J. R. Tybout (1995): An empirical model of sunk costs and the decision to export, vol. 1436. The World Bank.

ZIA, B. (2008): "Export Incentives, financial constraints and the (mis)allocation of credit: Microlevel evidence from subsidized export loans," Journal of Financial Economics, 87, 498-527. 